\title{
KAJIAN PEMANFAATAN KULIT UBI JALAR UNGU (Ipomoea batatas L) TERFERMENTASI DALAM RANSUM TERHADAP KONSUMSI DAN NUTRISI RANSUM DAN EFISIENSI PENGGUNAAN RANSUM PADA ITIK BALI UMUR 22 MINGGU
}

\author{
BELAWA YADNYA T.G., GAGA PARTAMA IB., TRINADEWI A.A.A.S. DAN WIRAWAN IW. \\ Fakultas Peternakan, Universitas Udayana Jln.PB.Sudirman, Denpasar,Bali \\ E-mail : belawayadnya_fapet@yahoo.com
}

\begin{abstract}
RINGKASAN
Penelitian ini dilaksanakan bertujuan untuk mengetahui pengaruh pemanfaatan kulit ubi jalar ungu (Ipomoea batatas $\mathrm{L}$ ) terfermentasi dalam ransum terhadap konsumsi ransun dan nutrisi dan efisoensi penggunaan ransum pada itik Bali, umur 22 minggu. Menggunakan rancangan acak lengkap (RAL) dengan lima perlakuan yang terdiri atas ransum A (ransum tanpa mengandung ubi jalar ungu), ransum B mengandung $10 \%$ kulit ubi jalar ungu, ransum $\mathrm{C}$ mengandung 10\% kulit ubi jalar ungu terfermentasi, ransum D mengandung 20\% kulit ubi jalar ungu, dan ransum E mengandung 20\% kulit ubi jalar ungu terfermentasi. Setiap perlakuan terdiri atas empat ulangan dan setiap ungan terdiri atas lima ekor itik. Variabel yang diamati meliputi konsumsi ransum, konsumsi protein serat kasar dan antosianin dan kapasitas antioksidan ransum, serta efisiensi penggunaan ransum. Hasi penelitian menunjukkan bahwa pemberian ransum B, C, D dan E mengkonsumsi ransum, protein dan serat kasar yang lebih rendah $(\mathrm{P}<0,05)$, dan dapat meningkatkan konsumsi antosianin dan kapasitas antioksidan ransum $(\mathrm{P}<0,05)$ dibandingkan dengan perlakuan A. Pemberian kulit ubi jalar ungu fermentasi atau tanpa fermentasi dalam ransum dapat meningkatkan pertambahan bobot badan $(\mathrm{P}<0,05)$, sedangkan pada FCR terjadi penurunan secara nyata $(0,05)$ dibandingkan dengan pemberian perlakuan A.Dari hasil penelitian ini dapat disimpulkan bahwa pemberian kulit ubi jalar ungu (Ipomoea batatas L) dapat mengurangi konsumsi ransu, protein dan serat kasar serta dapat meningkatkan efisiensi penggunaan ransum.
\end{abstract}

Kata kunci : kulit ubi jalar terfermentasi, konsumsi ransum dan nutrisi, efisiensi dan itik Bali.

\section{STUDY THE USED OF FERMENTED PURPLE SWEET POTATO (Ipomoea batatas L) IN DIETS ON FEED CONSUMPTION, NUTRITION AND FEED EFFICIENCY OF BALI DUCK}

\begin{abstract}
ABSTRACK
This experimen was carried out to study the effect of fermented purple sweet potato (Ipomoea batatas $L$ ) in diets on diet consumption and nutrition and feed efficiency of bali duck. Five treatment diets were used in a completely randomized design (CRD) consisted of control diet A (diet without containing purple sweet potato skin, diet B containing 10\% purple sweet potato skin, diet C containing 10\% fermented purple sweet potato skin, diet D containing 20\% purple sweet potato skin, and diet E containing 20\% fermented purple sweet potato skin. Each treatment consisted of four replications and each replication consisted of five ducks. Variables observed in this study were diet consumption and crude protein, crude fibre, anthocyanin and antioxidant capacity. Feed efficiency consisted final body weight, body weight gain and feed convertion ratio (FCR). In general, the results showed that addition of fermented purple sweet potato in diets were significantly reduce the diets consumption, crude and crude fibre consumption, However, the anthocyanin intake and diet antioxidant capacity were higher in treatment B,C.D, and $\mathrm{E}$ comparedto the control diet $(\mathrm{P}<\mathrm{O}, \mathrm{O} 5)$. It was concluded that the presented fermented purple sweet potato skin in diets could reduced the diet consumption, crude protein and crude fibre intake, but on anthocyanin intake and diet antioxidant capacity were significantly different to the control group. and could improve the feed efficiency of Bali duck.
\end{abstract}

Key words : fermented purple sweet potato skin, diet consumption, nutrition, feed efficiency and bali duck. . 


\section{PENDAHULUAN}

Peningkatan produktivitas ternak sangat terkait dengan kesediaan bahan pakan, karena biaya produksi , terutama dari bahan pakan hampir 60\% biaya produksi dari bahan pakan (Nitis, 1980). Untuk mencukupi kebutuhan pakan ternak, maka perlu dimanfaatkan bahan pakan alternatif, diantaranya yang berasal dari limbah pertanian diantaranya kulit ubi jalar ungu (Ipomoea batatas L). Ubi jalar ungu sangat baik untuk kesehatan manusia, karena mengandung energi selatif tinggi, namun kandungan zat antosianin relatif tinggi (Suprapta et al., 2004), namun kandungan proteinnya relatif rendah Maka perlu difermentasi. Yadnya dan Trisnadewi, 2011), fermentasi pada ubi ubi jalar ungu (Ipomoea batatas L) dapat meningkatkan kadar protein dari 3,85\% menjadi $8,50 \%$, disamping itu juga terjadi peningkatan kadar antosianin dan antioksidan. Pemberian limbah dari pembuatan tepung ubi jalar ungu dari taraf 2,5\% sampai $10 \%$ dapat meningkatkan konsumsi ransum dan tidak berpengaruh terhadap efisiensi penggunaan ransum (Alfaatih et al., 2008). Yadnya et al., 2012) melaporkan pemberian ubi jalar ungu (Ipomoea batatas L) terfermentasi dapat meningkatkan kecernaan ransum, protein serta serat kasar dan secara langsung berpengaruh positif terhadap efisiensi penggunaan ransum dan retensi protein serta pertambahan bobot badan.Yadnya et al., 2014) melaporkan pemberian kulit ubi jalar ungu pada taraf $5 \%$ tidak berpengaruh terhadap konsumsi ransum dan pertambahan bobot badan, dan ternyata pemberian sampai $15 \%$ tidak berpengaruh, jika dibandingkan dengan pemberian ransum kontrol, namun pada efisiensi dapat meningkat secara nyata pada itik Bali berumur 3 sampai 12 minggu. Berdasarkan hal tersebut dilakuakn penelitian dengan judul: "Kajian pemanfaatan kulit ubi jalar ungu (Ipomoea batatas L) terfermentasi dalam ransum terhadap konsumsi dan nutrisi ransum dan efisiensi penggunaan ransum pada itik Bali, umur 22 Minggu.

\section{MATERI DAN METODE}

\section{Tempat dan lama Penelitian}

Penelitian tahap kedua meliputi : a) Penelitian kandang di deas Guwang, Kecamatan Sukawati, Kabupaten Gianyar. b) Penelitian uji karkas dan kualitas daging di Lab. Teknologi hasil ternak, Fakultas Peternakan, Unud. c) Uji profil antioksidan di Lab. analitik, Unud. d) Uji kimia daging di Lab. Nutrisi Makanan Ternak, Fapet, Unud, dan e) uji tekstur daging dengan metode histologi di Balai Besar Veteriner, Pegok, Denpasar.

\section{Itik}

Itik yang digunakan dalam penelitian adalah itik bali, umur 12 minggu yang diperoleh dari seorang pengepul itik yang berasal dari Kabupaten Gianyar sebanyak 150 ekor dengan kisaran berat 1073,21 \pm 15,01gr.

\section{Kandang dan perlengkapannya}

Dalam penelitian ini menggunakan kandang sistem battery colony berlantai dua sebanyak 28 petak. setiap petak kandang mempunyai ukuran panjang $70 \mathrm{~cm}$, lebar $70 \mathrm{~cm}$, dan tinggi $70 \mathrm{~cm}$. Kandang dilengkapi dengan tempat makanan, dan tempat minum yang terbuat dari bilah-bilah bambu yang letaknya disebelah luar, dan juga dilengkapi dengan tempat penampung kotoran serta penampung sisa makanan, dan juga dilengkapi dengan lampu untuk penerangan di waktu malam.

\section{Pengolahan Umbi Jalar Ungu}

Pengolahan umbi ubi jalar ungu dengan amoniasi dan biofermentasi umbi ubi jalar ungu berasal dari Tegallalang, Gianyar. Kapang Aspergillus niger berasal dari BPTP Bali (Guntoro), dan cairan rumen berasal rumah potong hewan yang berasal RPH, Sanggaran, Bali. Urea yang dipergunakan adalah urea teknis, sedangkan molases (tetes) berasal dari limbah pembuatan gula diperoleh di Poultry Tohpati.

Tabel 1. Komposisi Bahan Penyusuanan Ransum Itik Bali, umur 12 -22 minggu

\begin{tabular}{lrrrrr}
\hline \multirow{2}{*}{ Bahan Ransum *(\%) } & \multicolumn{5}{c}{ Perlakuan } \\
\cline { 2 - 6 } & A & B & C & D & \multicolumn{1}{c}{ E } \\
\hline Jagung kuning & 55,36 & 49,98 & 42,32 & 49,98 & 42,32 \\
Kacang kedelai & 9,37 & 12,45 & 13,88 & 12,45 & 13,88 \\
Bungkil kelapa & 11,31 & 9,82 & 7,28 & 9,82 & 7,28 \\
Tepung ikan & 10,13 & 8,10 & 10,20 & 8,10 & 10,20 \\
Dedak padi & 13,26 & 9,00 & 5,08 & 9,00 & 5,08 \\
Kulit ubi jalar ungu (KUJU) & - & 10 & 20 & - & - \\
KUJU terfermentasi & - & - & - & 10 & 20 \\
Mineral B12 & 0,50 & 0,50 & 0,50 & 0,50 & 0,50 \\
NaCl & 0,15 & 0,15 & 0,15 & 0,15 & 0,15 \\
Minyak Kelapa & - & - & - & 2,00 & 2,00 \\
\hline
\end{tabular}

Tabel 2. Kandungan Nutrisi Ransum Penelitian *

\begin{tabular}{lrrrrr}
\hline \multirow{2}{*}{ Kandungan nutrisi ransum } & \multicolumn{6}{c}{ Perlakuan } \\
\cline { 2 - 6 } & \multicolumn{1}{c}{ A } & \multicolumn{1}{c}{ B } & \multicolumn{1}{c}{ C } & \multicolumn{1}{c}{ D } & \multicolumn{1}{c}{ E } \\
\hline Metabolis energi (Kkal/kg) & 2900,00 & 2926,18 & 2926,25 & 2928,90 & $29,35,18$ \\
Protein Kasar (\%) & 18,28 & 17,93 & 18,18 & 17,86 & 18,08 \\
Lemak Kasar (\%) & 5,94 & 5,46 & 5,42 & 5,84 & 5,45 \\
Lamak kasar & 4,80 & 5,46 & 4,38 & 4,52 & 4,32 \\
Kalsium (\%) & 1,40 & 1,21 & 1,04 & 1,14 & 0,91 \\
Fosfor tersedia (\%) & 0,73 & 0,71 & 0,69 & 0,71 & 0,50 \\
\hline
\end{tabular}

Keterangan

A : ransum tanpa mengandung kulit ubi jalar ungu $B$ : ransum mengandung $10 \%$ kulit ubi jalar ungu tanpa fermentasi $C$ : ransum mengandung $10 \%$ kulit ubi jalar ungu

D : ransum mengandung $20 \%$ kulit ubi jalar ungu tanpa terfermentasi. E : ransum mengandung $20 \%$ kulit ubi jalar ungu terfermentasi.

*Yadnya et al., (2015) 


\section{Biofermentasi dengan larutan Aspergillus niger}

Kulit ubi jalar ungu ditumbuk sampai halus dicampur dengan larutan Arpergillus niger sampai dikepal tidak terurai, dan dimasukkan kedalam karung goni dan dinkubasi selama satu minggu. Setelah difermentasi kemudian dikeringkan dan siap digunakan untuk penelitian

\section{Rancangan Percobaan}

Rancangan percobaan yang digunakan adalah rancangan acak lengkap (RAL) dengan tlima perlakuan yaitu ransum tanpa kulit ubi jalar atau tanpa difermentasi (perlakuan A), ransum mengandung 10\%, 20\%, kulit ubi jalar ungu tanpa fermentasi (perlakuan B dan, C ), ransum mengandung 10\% dan 20\% ubi jalar ungu terfermentasi (perlakuan D dan E). Setiap perlakuan dengan empat ulangan, dan setiap ulangan berisi 5 ekor itik dengan umur dan berat yang homogen (Yadnya et al., 2015)

\section{Variabel yang Diamati}

Variabel yang diamati dalam penelitian ini adalah sebagai berikut ini :

- Konsumsi ransum yaitu ransum yang diberikan dikurangi dengan sisa makanan, dan pengamatan dilakukan setiap minggu.

- Konsumsi nutrisi ransum yaitu jumlah konsumsi yang diransum dikalikan dengan kandungan zatzat nutrisi (protein, serat kasar, antosianin dan kapasitas antioksidan)

- Konversi Ransum adalah perbandingan antara ransum yang dikonsumsi dengan pertambahan bobot badan

\section{Analisis Data}

Data yang diperoleh dianalisis dengan sidik ragam dan apabila terdapat perbedaan yang nyata diantara perlakuan dilanjutkan dengan uji Duncan (Steel dan Torrie, 1989)

\section{HASIL DAN PEMBAHASAN}

\section{Konsumsi Ransum}

Konsumsi ransum selama 10 minggu pada itik Bali yang diberi ransum tanpa kulit ubi jalar ungu sebagai ransum kontrol (A) adalah 6,594 kg/ekor (Tabel 3). Pemberian ransum dengan kandungan kuli ubi jalar ungu tanpa fermentasi terjadi penurunan konsumsi ransum secara nyta $(\mathrm{P}>0,05)$, namun dengan pemberian kulit ubi jalar ungu tefermentasi (perlakuan C), pemberian ransum dengan 20\% kulit ubi jalar ungu tanpa atau terfermentasi (perlakuan D dan D) dapat menurunkan konsumsi ransum secara nyata $(\mathrm{P}<0,05)$ daripada pemberian ransum kontrol (perlakuan A).

Konsumsi ransum pada itik yang mendapatkan
10\% kulit ubi jalar ungu tanpa fermentasi, sedangkan dengan pemberian perlakuan C, D dan E mengkonsumsi ransum lebih rendah secara nyata dibandingkan dengan pemberian perlakuan kontrol. Hal ini disebabkan karena adanya enzim-enzim yang terdapat dalam Aspergillus niger. Muchtadi (1992), di dalam Aspergillus niger terdapat enzim selulase, protease dan lipase. Yadnya et al.,(2012), itik yang mendapatkan ransum ubi jalar ungu terfermentasi mengkonsumsi ransum dan konsumsi protein, lemak dan serat kasar yang lebih rendah daripada pemberian ransum tanpa ubi jalar ungu. Itik yang mendapatkan ransum mengandung kulit ubi jalar ungu terfermentasi atau tanpa fermentasi mengkonsumsi dapat menurunkan konsumsi protein dan serat kasar. Hal ini disebabkan karena dengan adanya kulit ubi jalar ungu terfermentasi.

\section{Konsumsi Antosianin}

Itik yang mendapatkan perlakuan A mengkonsumsi antosianin selama 10 minggu sebanyak 160,66 gr/ekor, amun pemberian perlakuan B, C, D dan E dapat meningkatkan konsumsi antosianin secara nyata $(\mathrm{P}<0,05)$. Pemberian perlakuan E lebih rendah daripada pemberian perlakuan $\mathrm{B}, \mathrm{C}$ dan $\mathrm{D}(\mathrm{P}<0,05)$.

Pemberian ransum yang mengandung kulit ubi jalar ungu tanpa atau fermentasi dapat menigkatkan konsumsi antosianin dan kapasitas antioksidan ransum Adanya Aspergillus niger dapat meningkatkan kandungan antosianin dan antioksidan ransum (Yadnya dan Trisnadewi, 2011), terjadi peningkatan kadar antosiani dari 22,0 mg/10ogr menjadi 50,00mg/10ogr, dan pada serta kasar terjadi penurunan yang menyebabkan ransum yang dikonsumsi lebih sedikit daripada pemberian perlakuan A. Yadnya et al., (2014) melaporkan pemberian daun ubi jalar ungu, daun mengkudu dan daun sirih sebagai sumber antioksidan dapat meningkan konsumsi antosianin dan antioksidan secara nyata dibandingkan itik yang mendapatkan ransum kontrol.

\section{Kapasitas Antioksidan}

Kapasitas antioksidan ransum pada itik A adalah 59,60 \% (Tabel 3). Pemberian perlakuan B, C, D dan E kapasitasnya meningkat secara nyata $(\mathrm{P}<0,05)$ daripada pemberian perlakuan A. Pemberian perlakuan B, C dan D kapasitas antioksidan lebih rendah daripada pemberian perlalkuan $\mathrm{E}(\mathrm{P}<0,05)$.

\section{Konsumsi Protein}

Konsumsi protein pada itikA adalah $1,17 \mathrm{okg} /$ ekor selama 10 minggu (Tabel 3). Itik yang mendapatkan perlakuan $\mathrm{B}$ dan $\mathrm{C}$ lebih rendah, namun tidak berbeda nyata $(\mathrm{P}>0,05)$, sedangkan pemberian perlakuan $\mathrm{B}$ lebih tinggi dan dengan pemberian perlakuan lebih rendah $(\mathrm{P}<0,05)$ daripada pemberian perlakuan $\mathrm{A}$. 
Tabel 3. Kajian Pemanfaatan Kulit Ubi Jalar Ungu (Ipomoea batatas L) terfermentasi dalam Ransum terhadap Konsumsi dan Nutrisi Ransum (Antosianin, antioksidan, protein dan serat kasar) pada Itik Bali

\begin{tabular}{|c|c|c|c|c|c|c|}
\hline \multirow{2}{*}{ Variabel } & \multicolumn{5}{|c|}{ Perlakuan } & \multirow{2}{*}{ SEM } \\
\hline & A & B & C & D & $E$ & \\
\hline $\begin{array}{l}\text { Konsumsi Ransum } \\
\text { (g/ekor/10minggu) }\end{array}$ & $6594,50 a$ & $6592,5 a$ & $6452,5 b$ & $6410,0 \mathrm{~b} 62$ & $247,30 c$ & 38,26 \\
\hline $\begin{array}{l}\text { Konsumsi } \\
\text { Antosianin } \\
\text { (g/ekor/10minggu) }\end{array}$ & $160,66 d$ & $175,35 c$ & $173,70 c$ & $183,32 b$ & $298,0 a$ & 0,477 \\
\hline $\begin{array}{l}\text { Kapasitas } \\
\text { antioksidan (\%) }\end{array}$ & $59,60 a$ & $74,26 \mathrm{~b}$ & $74,28 b$ & $76,86 c$ & $80,53 d$ & 18,25 \\
\hline $\begin{array}{l}\text { Konsumsi } \\
\text { Protein (kg/ } \\
\text { ekor/10minggu) }\end{array}$ & 1,170ab & $1,181 a$ & $1,165 b$ & 1,169ab & $1,269 c$ & 0,004 \\
\hline $\begin{array}{l}\text { Konsumsi serat } \\
\text { Kasar (Kg/ } \\
\text { ekor/10minggu) }\end{array}$ & $0,383 a$ & $0,359 b$ & $0,297 c$ & $0,281 d$ & $0,269 e$ & 0,002 \\
\hline
\end{tabular}

Superskrip dengan nilai yang berbeda pada kolom yang sama berati berbeda nyata $(\mathrm{P}<0,05)$

Pemberian kulit ubi jalar ungu (Ipomoea batatas L) terfermentasi dapat meningkatkan konsumsi protein, karena adanya enzim-enzim dalam Aspergillus niger mengandung enzim selulase yang dapat merubah polisakarida menjadi senywa karbohidrat yang sederhana, misalnya senyawa monosakarida diantaranya adalah glukosa. Enzim lipase dapat menghidrolisa lemak menjadi asam-asam lemak dan gliserol, dan enzim proteolitik dapat merubah protein menjadi asam-asam amino (Varzakas et al., 2007 dan Muchtadi, 1992), yang menyebabkan kecernaan ransum dapat meningkat secara nyata (Yadnya et al., 2012), sehingga zat nutrisi yang diserap lebih banyak dan akan berpengaruh terhadap pertambahan bobot badan yang dihasilkan akan lebih tinggi serta bobot badan akhir yang dihasilkan lebih tinggi, sehingga jumlah ransum yang dikonsumsi dibagi dengan pertambahan bobot badan yang lebih rendah, yang berarti pemberian ransum yang mengandung kulit ubi jalar ungu terfermentasi dapat memperbaiki efisiensi penggunaan ransum. Yadnya et al.(2012) mendapatkan pemberian ubi jalar ungu terfermentasi dapat meningkatkan pertambahan bobot badan dan dapat menurunkan nilai FCR (Feed Conversion Rasio).

\section{Konsumsi Serat Kasar}

Konsumsi serat kasar pada itik yang mendapatkan perlakuan A selama 10 minggu adalah $0,383 \mathrm{~kg} / \mathrm{ekor}$. Pemberian ransum yang mengandung kulit ubi jalar ungu tanpa atau terfermentasi (perlakuan B, C, D dan E) mengkonsumsi serat kasar lebih rendah $(\mathrm{P}<0,05)$ daripada pemberian perlakuan A. Pemberian pemberian perlakuan $\mathrm{E}$ lebih rendah $(\mathrm{P}<0,05)$ daripada pemberian perlakuan B, C, dan E.

\section{Bobot Badan Akhir}

Bobot badan akhir pada itik yang mendapatkan ransum kontrol (A) pada umur 22minggu adalah 1475,og (Tabel 4). Pemberian perlakuan B, C, D dan E dapat meningkatkan bobot badan akhir secara nyata $(\mathrm{P}<0,05)$ daripada pemberian perlakuan A. Pemberian perlakuan $\mathrm{B}, \mathrm{C}$ dan $\mathrm{D}$ lebih rendah daripada perlakuan $\mathrm{E}(\mathrm{P}<\mathrm{O}, 05)$, sedangkan diantara perlakuan $\mathrm{B}, \mathrm{C}$ dan $\mathrm{D}$ tidak berbeda nyata $(\mathrm{P}>0,05)$.

\section{Pertambahan Bobot Badan}

Pertambahan bobot badan pada itik yang mendapatkan perlakuan A adalah 405,o g. Pemberian perlakuan B, C, D dan $\mathrm{E}$ dapat meningkatkan pertambahan bobot badan secara nyata $(\mathrm{P}<0,05)$ daripada pemberian perlakuan A.

"Feed convertion ratio" (FCR) pda itik A adalah 16,oo. Pemberian perlakuan C, D dan E dapat menurunkan FCR secara nyata $(\mathrm{P}<0,05)$, sedangkan pemberian perlakuan $\mathrm{B}$ tidak berbeda nyata $(\mathrm{P}>0,05)$ dengan pemberian perlakuan kontrol (A).

Tabel 4. Efisiensi Penggunaan Ransum pada itik yang mendapatkan Kulit Ubi Jalar Ungu (Ipomoea batatas L) Terfermentasi dalam Ransum selama 10 Minggu

\begin{tabular}{lcccccc}
\hline \multirow{2}{*}{ Variabel } & \multicolumn{5}{c}{ Perlakuan } \\
\cline { 2 - 6 } & $\mathrm{A}$ & $\mathrm{B}$ & $\mathrm{C}$ & $\mathrm{D}$ & $\mathrm{E}$ & \\
\hline $\begin{array}{l}\text { Konsumsi } \\
\text { Ransum (g/ } \\
\text { ekor) }\end{array}$ & $6594,5 \mathrm{a}$ & $6592,5 \mathrm{a}$ & $6453,3 \mathrm{~b}$ & $6410,0 \mathrm{~b}$ & $6247,3 \mathrm{c}$ & 38,26 \\
$\begin{array}{l}\text { Bobot badan } \\
\text { akhir (g/ekor) }\end{array}$ & $1475,0 \mathrm{c}$ & $1513,5 \mathrm{~b}$ & $1517,5 \mathrm{~b}$ & $1527,5 \mathrm{~b}$ & $1572,5 \mathrm{a}$ & 11,68 \\
$\begin{array}{l}\text { Pertambahan } \\
\text { bobot badan } \\
\text { (g/ekor) }\end{array}$ & $405,0 \mathrm{c}$ & $445,0 \mathrm{~b}$ & $445,0 \mathrm{~b}$ & $455,0 \mathrm{~b}$ & $500,0 \mathrm{c}$ & 0,0004 \\
\begin{tabular}{l} 
FCR \\
\hline
\end{tabular} & $16,28 \mathrm{a}$ & $14,81 \mathrm{ab}$ & $14,50 \mathrm{~b}$ & $14,08 \mathrm{~b}$ & $12,49 \mathrm{c}$ & 0,394 \\
\hline
\end{tabular}

Superskrip dengan nilai yang berbeda pada baris yang sama adalah berbeda nyata $(\mathrm{P}<0,05)$

Berdasarkan penjelasan pada hasil dan pembahasan hasil penelitian, maka dapat disimpulkan bahwa pemberian kulit ubi jalar ungu (Ipomoea batatas L) terfermentasi dalam ransum dapat mengurangi konsumsi ransum, meningkatkan konsumsi antosianin dan antioksidan serta dapat mengurangi konsumsi seratkasar, dan meningkatkan efisiensi penggunan ransum

\section{UCAPAN TERIMAKASIH}

Ucapan terimakasih penulis aturkan kepada Direktorat Penelitian dan Pengabdian kepada Masyarakat, Direktorat Jendral Pendidukan Tinggi, Kementerian Pendidikan dan Kebudayaan melaui Rektor Universitas Udayana atau Lembaga Penelitian dan Pengabdian kepada Masyarakat, Universitas Udayana atas dana penelitian yang telah diberikan melalui surat Perjan- 
jian Penugasan Pelaksanaan Penelitian, Nomor : 178/ UN14.2/PNL.01.03.00/2015, tanggal 3 Maret 2015, sehingga penelitian dapat terlaksana dengan semestinya.

\section{DAFTAR KEPUSTAKAAN}

Alfaatih,M; Eko Widodo; dan Halim Natsir M.. 2008. Tingkat penggunaan limbah ubi jalar ungu (Ipomoea batatas L) dalam ransum terhadap performan Produksi ayam pedaging. Jurusan Nutrisi Makanan Ternak, Fapet, UB. File://D:/ampas\%ketela\%2oungu.htm. Diakses 19/08/2010, $21: 12$.

Muchtadi. 1992. Enzim dalam pangan. Depdikbud. Dikti. Pusat Antar Universitas, Pangan dan Gizi, IPB, Bogor.

Nitis, I M. 1980. Makanan Ternak Salah Satu Sarana untuk Meningkatkan Produksi Ternak. Orasi Ilmiaah Pengukuhan Guru Besar dalam Ilmu Makanan Ternak, Fakultas Peternakan, Universitas Udayana, Denpasar, Bali.

Steel RGD., dan J.H.Torrie. 1989. Prinsip dan Prosedur Statistika . Suatu Pendekatan Biometrik. Penerbit PT Gramedia Pustaka Utama, Jakarta.

Varzakas,TH; Roussos S; Arvanitoyannis, IS. 2007. Glucoamylases production of Aspergillus niger in solid stateb fermentation using conyinuous countercurrent reactor. International Journal of Food Science and Technology. Vol. 43, Issue 7, Pp1159 - 1168.
Yadnya, TGB.dan A.A.A.S.Trisnadewi. 2011. Improving the nutrition of Purple Sweet Potato (Ipomoea batatas L) Through Biofermentation of Aspergillusniger as Feed Substance Containing Antioxidants.Prooceedings $3^{\text {rd }}$ Internatioanl Conference on Biosciences and Biotechnology, Maintaning World Prosperity ThroughBioscences and Biotechnology and Revegetation, Bali, September $21^{\text {st }}-22^{\text {nd }}, 2011$.

Yadnya,TGB; Partama IBG., dan Trisnadewi A.A.A.S.. 2012. Pengaruh pemberian ransum Ubi Jalar Ungu (Ipomoea batatas L) terfermentasi Aspergillus niger terhadap Kecernaan Ransum, retensi Protein, dan Pertambahan Bobot Badan pada Itik Bali. Prosiding seminar Nasional Fakultas Agro Industri, Universitas Mercu Buana, Yogyakarta, ISBN: 978 - 18810-0-2.

Yadnya, TGB. Partama IBG., Trisnadewi A.A.A.S., dan Wirawan IW. 2014. Kajian Pengaruh Pemanfaatan Kulit Ubi Jalar Ungu (Ipomoea batatas L) terfermentasi dalam ransum terhadap nilai nutrisi ransum, penampilan, Malondialdehide (MDA), gula dan asam urat Darah itik Bali Fase Pertumbuhan. Laporan Penelitian, Fakultas Peternakan universitas Udayana dengan Sumber Dana Penelitian Hibah Unggulan Dikti. Tahun Anggaran 2014. 